\title{
Analysis of Phytoconstituents and Biological Activities of Different Parts of Mahonia nepalensis and Berberis aristata
}

\author{
Rojeena Thusa*, Sushika Mulmi
}

Central Department of Chemistry, Tribhuvan University, Kirtipur, Nepal

\begin{abstract}
The phytochemicals and biological activities of extracts from leaves and stem of Mahonia nepalensis and Berberis aristata were carried out. Phytochemical screening showed the presence of alkaloids, steroids, polyphenols, quinones, glycoside, flavonoid, terpenoid and cardiac glycoside in the hexane, ethyl acetate and methanol extracts of leaf and stem of these two plants. The column chromatography of methanol extract of stem of Mahonia nepalensis resulted in isolation of four pure compounds $\mathrm{MN}_{1}, \mathrm{MN}_{2}, \mathrm{MN}_{3}$ and $\mathrm{MN}_{4}$. Out of four isolated compounds, two were identified as $\mathrm{MN}_{1}: \beta$ - sitosterol and $\mathrm{MN}_{2}$ : Berberine by comparison of melting point, Co-TLC, IR and UV spectra of authentic sample. Potent pharmacological activity of Mahonia nepalensis and Berberis aristata were revealed from antimicrobial activity and brine shrimp bioassay. Methanol extracts of stem of Mahonia nepalensis and Berberis aristata showed significant zone of inhibition of $18 \mathrm{~mm}$ and $21 \mathrm{~mm}$ respectively against the Staphylococcus aureus. Methanol extract of Berberis aristata were comparatively little stronger against Staphylococcus aureus than methanol extract of Mahonia nepalensis. LC $\mathrm{L}_{50}$ values $(\mu \mathrm{g} / \mathrm{ml})$ of methanol extracts of stem of Berberis aristata and Mahonia nepalensis were found to be $8.058 \times 10^{-4}$ and 8.3 whereas methanol extracts of leaf of Mahonia nepalensis and Berberis aristata were 389.04 and 1303.166 respectively.
\end{abstract}

Key words: Mahonia nepalensis, Phytochemical, Berberis aristata, $\mathrm{LC}_{50}$ values,

*Corresponding Author

Email: rojeenathusa@gmail.com

\section{Introduction}

Nepal is well known for superb collection of medicinal and aromatic plant resources that grow luxuriously in tropical forests to alpine meadow [1]. Since past, parts of these medicinal plants or their extracts have been used as traditional medicine. Traditional medicines are safe, easily accessible and affordable form of health care for much of the rural population in Nepal. Plants used in traditional medicine are important sources of novel biomolecules with application for the manufacture of pharmaceuticals and cosmeceuticals [2].

Berberidaceace is a family of shrubs and herbs, mainly of the Northern temperate zone, with simple, pinnate, or peltate leaves with spines. There are 14 genera in this family, and Mahonia and Berberis are among them. Mahonia is readily distinguished from Berberis by its compound leaves, spineless stems and inflorescence of several dense spikes. Berberis is distinguished by its undivided spiny toothed leaves and its spiny stems with yellow wood [3].

Mahonia nepalensis belongs to the family Berberidaceae and is known vernacularly as "Jamanemandro" in Nepali and "Michiki swan" in Newari. It is medium sized fully hardy perennial evergreen shrub with yellow flowers in winter. This shrub has an ultimate height of $6 \mathrm{~m} / 19.7 \mathrm{ft}$. Its origin is in Nepal. It is widely distributed in the high mountainous areas at altitude of about $1000 \mathrm{~m}-2000 \mathrm{~m}$ in Nepal, Sikkim, Bhutan, China, Vietnam, etc. It is useful in architectural and security barrier in garden, traditional essential flower for conducting Bel Bibaha and Bratabanda in Newar community. The stem and wood of this plant have antiinflammatory, anti-bacterial, anti-fungal activity. It is particularly used for the treatment of skin diseases like eczema, psoriasis, etc. This plant contains alkaloids as the major compounds which belong to class protoberberines and bisbenzylisoquinolines [4] Berberine [5], Jattrrorzhine, O-methyl puljabine [6], Isotetradine, Homoaromaline etc. were isolated from the stem of this plant [7].

Berberis aristata also belongs to Berberidaceace family and is commonly known as "Chutro" in Nepali, "Daruhaldi" in Hindi and "Indian Berberry" in English. It is spinous herb native to northern Himalaya region, widely distributed from Himalayas to Sri Lanka, Bhutan and hilly areas of Nepal. It is used in ayurvedic medicine from very long time. The plant is used traditionally in inflammation, diarrhea, wound healing, skin disease, menohrrhagia, jaundice, and affection of eyes. A very valuable ayurvedic 
preparation" Rashut" is prepared from this plant [5]. It is useful in treatment of jaundice, diabetes, cancer, malaria etc. and has good anti-oxidant property, anti-pyretic activity, analgesic activity, anti-fungal activity and anti-microbial property, anti-inflammatory, anti-platelet activating factor [8].

Berberine, Berbamine [9], Oxycanthine, Epiberberine, Palmatine, Dehydrocaroline, Jattrorhizine, Columbamine, Dihydrokarachine, Karachine [10], Taximaline [11], Oxyberberine, Aromaline [12], Pakistanine, 1-O-methyl Pakistanine [13], Pseudo Palmatine chloride, Pseudo berberine chloride, Lanost-5-en- $\beta$-ol [14] were isolated from its stem while citric acid, malic acid from fruit and E-caffeic acid, quercetin, chlorogenic acid, meratin and rutin from flower have also been isolated from this plant [15].

Due to their important pharmaceutical importance, we have tried to isolate the plant metabolites and determine the photoconstituents of different parts of these two valuable plants and studied their biological properties, isolated some of the important compounds and tried to characterize and identify the isolated compound as well.

\section{Materials and Method Sample collection and extraction}

The stem and leaves of Mahonia nepalensis and Berberis aristata were collected from Bhaktapur and Palpa district respectively in April, 2013 and thoroughly dried in shade. About $50 \mathrm{~g}$ of stem and leaves of the two plants were ground to fine powder. The grinded parts were then successively extracted with hexane, ethyl acetate and methanol on the basis of their increasing polarity by using Soxhlet apparatus. The extracts were concentrated using rotatory evaporator and left for removal of solvent. After the solvents were completely removed, they were used for different purposes like phytochemical screening, biological activities study and isolation of chemical constituents.

\section{Phytochemical screening}

A small amount of dry extracts of plant materials were subjected to phytochemical screening. The method employed was based on the standardized procedure with slight modification [16-18].

\section{Test for Tannin/Polyphenols}

To a portion of extract diluted with water, 3-4 drops of $10 \% \mathrm{FeCl}_{3}$ is added, a blue color was observed for gallic, tannins and green color for catecholic tannin.

\section{Test for Reducing Sugar}

To $0.5 \mathrm{ml}$ of plant extract, $1 \mathrm{ml}$ of water and $5-8$ drops of Fehling's solution was added and heated over water bath. Brick Red precipitate indicated the presence of reducing sugar.

\section{Test for Quinines}

To the extract, Freshly Prepared $\mathrm{FeSO}_{4}$ Solution (1ml) and Ammonium Thiocyanate (few crystals) were added and treated with conc. $\mathrm{H}_{2} \mathrm{SO}_{4}$ drop by drop. The deep red color was persistent indicating the presence of quinines.

\section{Test for Glycosides}

For testing the glycosides, the protocol was slightly modified. To the extract, $5 \mathrm{ml}$ Molisch's reagent was added and conc. $\mathrm{H}_{2} \mathrm{SO}_{4}$ was added drop wise without disturbing the solution. A violet ring at the junction of two liquids was observed and on shaking the solution turned violet completely indicating the presence of glycosides.

\section{Test for Flavonoid}

i. Shinoda test: $4 \mathrm{ml}$ of extract solution was treated with $1.5 \mathrm{ml}$ of $50 \%$ methanol solution. The solution was warmed and metal magnesium was added. To this solution, 5-6 drops of conc. $\mathrm{HCl}$ was added and red color was observed for flavonoid and orange color for flavones.

ii. $5 \mathrm{ml}$ of dilute $\mathrm{NH}_{3}$ solution was added to the aqueous filtered solution of each fraction followed by the addition of conc. $\mathrm{H}_{2} \mathrm{SO}_{4}$. The appearance of yellow color indicated the presence of flavonoid. The yellow color disappeared after some time.

\section{Test for Terpenoid}

About $0.2 \mathrm{~g}$ of each sample was mixed with $2 \mathrm{ml}$ of chloroform first and $3 \mathrm{ml}$ of conc. $\mathrm{H}_{2} \mathrm{SO}_{4}$ was 
added to each mixture. The formation of a reddish brown coloration at the interface indicates the presence of terpenoid.

\section{Test for Alkaloids}

I. Meyer's Test: To $2 \mathrm{ml}$ of extract, $1 \mathrm{ml}$ of Meyer's reagent (picric acid solution) was added. White precipitate and pale yellow precipitate indicates presence of alkaloids.

ii. Dragendroff's Reagent Test: $2 \mathrm{ml}$ of extract and each fraction were warmed with $2 \% . \mathrm{H}_{2} \mathrm{SO}_{4}$ for $2 \mathrm{~min}$. After filtration of the reaction mixture a few drops of Dragendroff's reagent were added to each filtrate. Orange red precipitate indicates presence of alkaloids.

\section{Test for Saponins}

About $2 \mathrm{~g}$ of powdered sample was boiled in $20 \mathrm{ml}$ of distilled water in a water bath and filtered $10 \mathrm{ml}$ of filtrate was mixed with $5 \mathrm{ml}$ of distilled water and shaken vigorously. The appearance of frothing indicated the presence of saponins.

\section{Test for Volatile oils}

$2 \mathrm{ml}$ extract was shaken with $0.1 \mathrm{ml}$ of $\mathrm{NaOH}$ and a small quantity of dil. $\mathrm{HCl}$. A white precipitate was formed which indicated presence of volatile oils.

\section{Test for Cardiac Glycosides}

$5 \mathrm{ml}$ of plant extract was treated with $2 \mathrm{ml}$ of glacial acetic acid containing one drop of $\mathrm{FeCl}_{3}$ solution. A brown ring at the interface indicated a deoxy sugar characteristic of cardenolides. A violet ring was appeared below the brown ring, while in acetic acid; a greenish ring was formed just gradually throughout thin layer which showed the presence of cardiac glycosides.

\section{Test for Steroids}

$1 \mathrm{gm}$ of plant extract was dissolved in few drops of acetic acid. It was gently warmed and cooled under tap and a drop of conc. $\mathrm{H}_{2} \mathrm{SO}_{4}$ was added alongside of tube. Appearance of green color indicated presence of steroids.

\section{Separation of compound by using column chromatography}

$23.2 \mathrm{~g}$ methanol extract of stem of Mahonia nepalensis was adsorbed in $20.07 \mathrm{~g}$ silica gel (60120) mesh and loaded in the column having diameter $3 \mathrm{~cm}$ and length $60 \mathrm{~cm}$ packed with150 mg activated silica gel (60-120)mesh. The $40.5 \mathrm{~cm}$ long column was eluted with gradient of hexane, ethyl acetate, and methanol to obtain no. of fractions which resulted in isolation of compound $\mathrm{MN}_{1}$, compound $\mathrm{MN}_{2}$, compound $\mathrm{MN}_{3}$ and compound $\mathrm{MN}_{4}$. Compound $\mathrm{MN}_{1}$ was obtained on concentration of fraction (25-27) in rotator evaporator while Compound $\mathrm{MN}_{2}$ from fraction (190-191), compound $\mathrm{MN}_{3}$ and $\mathrm{MN}_{4}$ from fraction (200-206),

Compound $\mathrm{MN}_{1}$ : Needle Shaped white crystals, Melting Point (MP) $135^{\circ} \mathrm{C}$, showed single spot on TLC with R.F value 0.43 (20\% Ethyl acetate in hexane).

Compound $\mathrm{MN}_{2}$ : Needle shaped yellow crystals, MP $-200^{\circ} \mathrm{C}-205^{\circ} \mathrm{C}$. (decomposed), showed single spot on TLC with R.F value 0.45 (20\% methanol in chloroform).

Compound $\mathrm{MN}_{3}$ : Needle shaped brown colored crystals, MP - $140^{\circ} \mathrm{C}$, showed single spot on TLC with R.F value $0.81 \quad(30 \%$ methanol in chloroform).

Compound $\mathrm{MN}_{4}$ : Needle shaped dark orange brown colored crystalline, MP $-140^{\circ} \mathrm{C}$ and decomposed at $160^{\circ} \mathrm{C}$, showed single spot on TLC with R.F value 0.86 (30\% methanol in chloroform).

\section{Antimicrobial tests}

The extracts of Mahonia nepalensis and Berberis aristata were screened for their antimicrobial activity i.e. determination of zone of inhibition against tested organism by Agar well diffusion method [19].

Four strains of bacteria namely Staphylococcus aureus, Kleibsella pneumonia (ATCC 700603), Salmonella typhimurium (ATCC 242), and Salmonella typhimurium (ATCC 14028) were used for antibacterial assay. Staphylococcus aureus and Kleibsella pneumonia were obtained from National Public Health Laboratory, Teku, Nepal and Salomonella typhimurium and Salmonella typhimurium were obtained from Institute of Medicine,

Maharajgunj, Nepal. These organisms were placed in Muller-Hinton Agar (MHA) in the refrigerator at $4^{\circ} \mathrm{C}$ prior to subculture. 
Table 1: Percentage yield of different plant extracts and their physical characteristics.

\begin{tabular}{llllll}
\hline Plant & part & Extract & \% Yield & color & consistency \\
\hline M. nepalensis & stem & hexane & 0.53 & yellow & sticky \\
M. nepalensis & stem & ethyl acetate & 4.2 & yellow & sticky \\
M. nepalensis & stem & methanol & 12.6 & dark orange & powdered \\
M. nepalensis & leaf & hexane & 4.6 & green & sticky \\
M. nepalensis & leaf & ethyl acetate & 6.8 & dark green & sticky \\
M. nepalensis & leaf & methanol & 22.4 & dark green & powdered \\
B. aristata & stem & hexane & 0.88 & yellow & sticky \\
B. aristata & stem & ethyl acetate & 5.8 & yellow & sticky \\
B. aristata & stem & methanol & 22.6 & dark orange & powdered \\
B. aristata & leaf & hexane & 1.2 & green & sticky \\
B. aristata & leaf & ethyl acetate & 1.8 & dark green & Sticky \\
B. aristata & leaf & methanol & 3.8 & Dark green & powdered \\
\hline
\end{tabular}

Agar well diffusion method was used to test the anti-bacterial properties of the crude extract and

Table 2: Phytochemical screening of different plant extracts

\begin{tabular}{|c|c|c|c|c|c|c|c|c|c|c|c|}
\hline Test & Tannin & $\begin{array}{l}\text { Reducing } \\
\text { sugar }\end{array}$ & Quinone & Glycoside & Flavonoid & Terpenoid & Alkaloid & Saponir & $\begin{array}{l}\text { Volatile } \\
\text { compd }\end{array}$ & $\begin{array}{l}\text { Cardiac } \\
\text { glycoside }\end{array}$ & Steroid \\
\hline HSM & - & - & ++ & + & - & +++ & + & - & - & + & +++ \\
\hline ESM & - & - & + & + & - & +++ & + & + & - & + & +++ \\
\hline MSM & - & - & +++ & + & +++ & +++ & +++ & + & - & + & +++ \\
\hline HLM & - & - & ++ & + & - & +++ & - & - & - & + & +++ \\
\hline ELM & - & - & + & + & - & +++ & - & + & - & + & +++ \\
\hline MLM & - & - & +++ & + & +++ & +++ & +++ & + & - & + & +++ \\
\hline HSB & - & - & ++ & + & - & +++ & + & - & - & + & +++ \\
\hline ESB & - & - & + & + & - & +++ & + & - & - & + & +++ \\
\hline MSB & - & - & +++ & + & +++ & +++ & +++ & - & - & + & +++ \\
\hline HLB & - & - & ++ & + & - & +++ & - & - & - & + & +++ \\
\hline ELB & - & - & + & + & - & +++ & - & - & - & + & +++ \\
\hline $\begin{array}{l}\text { MLB } \\
(+ \text { sig } 1\end{array}$ & $\begin{array}{c}+ \\
\mathrm{n} \text { indica }\end{array}$ & $\begin{array}{c}+ \\
\text { presence, }\end{array}$ & $\begin{array}{c}+++ \\
- \text { sign ind }\end{array}$ & $\begin{array}{c}+ \\
\text { icate absen }\end{array}$ & ce) ${ }^{+++}$ & +++ & +++ & - & - & + & +++ \\
\hline
\end{tabular}

MHA was used as medium. The bacterial inoculums were sub-cultured in Nutrient Broth for $12-18$ hours at $37^{\circ} \mathrm{C}$. Sterile petri plates were taken and MHA was poured, allowed to set and maintained the thickness of media at $4 \mathrm{~mm}$ in each plate. Seven wells were bored in the medium and extracts of five plant material, a standard antibiotic disc, Nalidixic acid $30 \mu \mathrm{g}$, as positive control and DMSO as solvent control was added into them. The inoculated plates were incubated at $37^{\circ} \mathrm{C}$ for $18-24$ hrs and the diameters of the zone of inhibition of microbial growth were measured in millimeters.

\section{Brine Shrimp Bioassay}

Brine shrimp Bioassay was performed using standard procedure. Brine shrimp eggs were hatched in artificial sea water. The Brine Shrimp larvae were cultured under prescribed laboratory condition [20] and used against methanol extracts. The number of survived shrimps was counted and $\mathrm{LC}_{50}$ value was calculated.

\section{Result and Discussion Isolation of Plant Metabolites}

The different parts of plants specially leaf and stem selected on the basis of their medicinal use in Ethno medicine were successively extracted on the basis of increasing polarity. The yield of these extract and their physical characteristic were shown in (Table 1).

The highest yield \% was observed for the methanolic extract of stem of B.aristata and was found to be 22.6 while the yield \% for methanolic extract of stem of Mahonia nepalensis 
was only $12.6 \%$.Similarly the highest yield \% of methanolic leaf extract of Mahonia nepalensis was 22.4 whereas the yield \% of methanolic leaf extract of B.aristata was only $3.8 \%$. Hexane extract were generally sticky and has comparatively low yield while ethylacetate extract yield was medium.

\section{Phytochemical Screening}

The phytochemical screening of all plant materials were done on the basis of the procedure given by Alamzeb K (2013), Talukdar and Chaudhary (2010), and Prof. I. Culie (1990) [16-18]. The results obtained are given below in Table 2.

\section{Isolation and Identification from Stem of $M$. nepalensis}

Compound $\mathbf{M N}_{1}$ : The compound $\mathrm{MN}_{1}$ was white crystalline having $\mathrm{MP} 135^{\circ} \mathrm{C}$ and showed single spot on TLC in 20\% Ethylacetate in Hexane solvent system with R.F value 0.43 . It gave greenish red test in Liberman Burchard Test which indicated that the compound was sterol. It was identified as $\beta$-Sitosterol with the help of Co-TLC and melting point. The structure of $\beta$-Sitosterol (Figure 1).

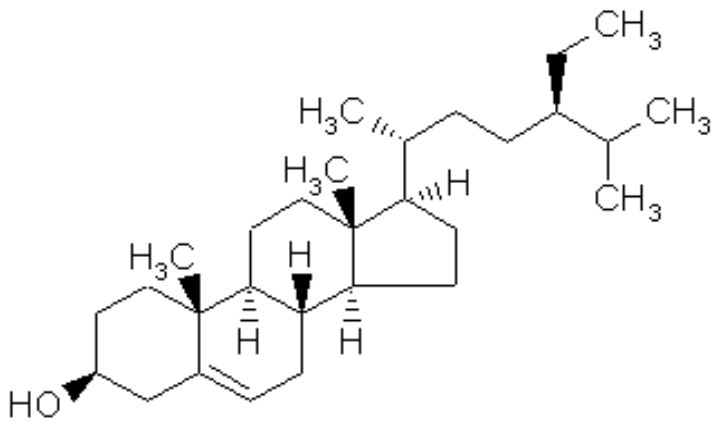

Figure 1: Chemical Structure of $\beta$-Sitosterol

Compound $\mathbf{M N}_{2}$ : The compound $\mathrm{MN}_{2}$ is needle shaped yellow colored crystalline compound having MP. $200^{\circ} \mathrm{C}-205^{\circ} \mathrm{C}$ (decomposed). It showed a clear single spot on TLC in $20 \%$ methanol in $\mathrm{CHCl}_{3}$ solvent system with R.F value 0.4. It gave pale yellow precipitate in Meyer's test and orange red precipitate in Dragendroff's test which indicated that the compound was alkaloid. The IR spectra showed peaks of $3549 \mathrm{~cm}^{-1}, 3402 \mathrm{~cm}^{-1}, 3317 \mathrm{~cm}^{-1}, 3224 \mathrm{~cm}^{-1}$ (N-H stretch ), $3055 \mathrm{~cm}^{-1}$ (C-H stretch in aromatic functional group),2908 $\mathrm{cm}^{-1}, 2846 \mathrm{~cm}^{-}$ ${ }^{1}$ (C-H stretch of alkenes), $2121 \mathrm{~cm}^{-1}$ (C triple bond $\mathrm{N}$ stretch), $1605 \mathrm{~cm}^{-1}$ (C-C stretch in ring, aromatic), $1396 \mathrm{~cm}^{-1}, \quad 1365.60 \quad \mathrm{~cm}^{-1}(\mathrm{C}-\mathrm{H}$ bending)), $1293.02 \mathrm{~cm}^{-1}, 1204.44 \mathrm{~cm}^{-1}$ (C-O stretch C-N stretch in aromatic amines), 1111 $\mathrm{cm}^{-1}, 1041 \mathrm{~cm}^{-1}$ (C-O-C bending), $970 \mathrm{~cm}^{-1}(\mathrm{O}-\mathrm{H}$ bending), $887 \mathrm{~cm}^{-1}, 825 \mathrm{~cm}^{-1}, 640 \mathrm{~cm}^{-1}, 524 \mathrm{~cm}^{-1}$, $424 \mathrm{~cm}^{-1}, 393 \mathrm{~cm}^{-1}$ (C-H out of plane bending) which were identical with that of the authentic sample of Berberine (Figure 3 and 4). The UV spectrum of the isolated compound showed that max wavelength of $353.8 \mathrm{~nm}$ at $0.861 \mathrm{~A}$, min wavelength of $307 \mathrm{~nm}$ at $0.310 \mathrm{~A}$ and $\max$ wavelength $271.6 \mathrm{~nm}$ at $2.267 \mathrm{~A}$ and $\mathrm{min}$ wavelength $251.8 \mathrm{~nm}$ at $0.335 \mathrm{~A}$. These UV spectral data of isolated compound were also found to be identical with that of authentic sample of Berberine (Figure 5 and 6) respectively. Comparing the spectral data of IR Spectra and UV spectra and melting point with reference to the authentic sample, it was identified that the compound $\mathrm{MN}_{2}$ was Berberine. The structure of Berberine (Figure 2).

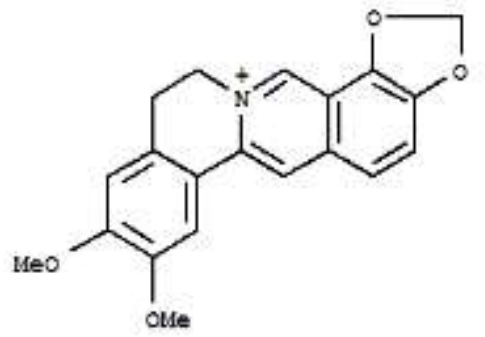

Figure 2: Chemical Structure of Berberine

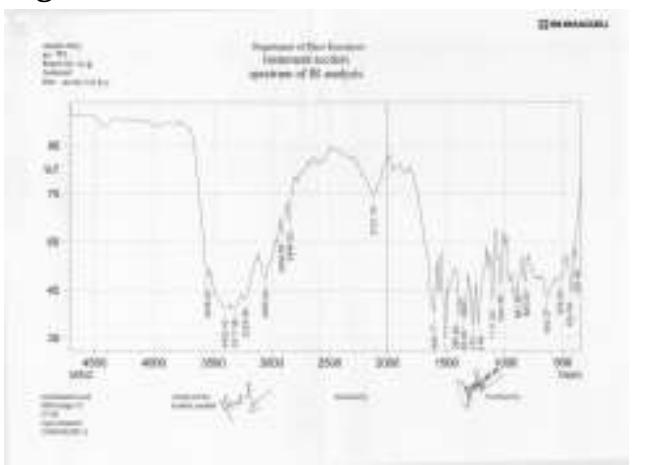

Figure 3: IR Spectrum of $\mathrm{MN}_{2}$ 


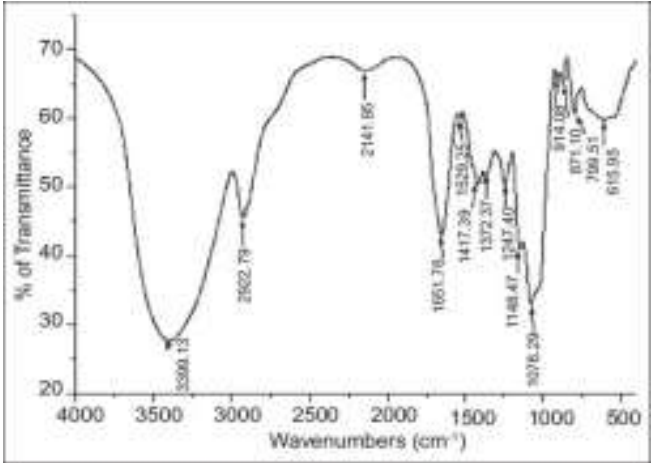

Figure 4: IR Spectrum authenticated berberine

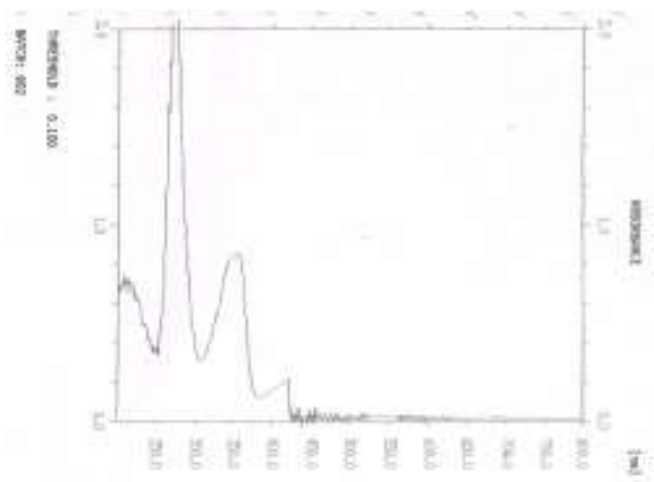

Figure 5: UV Spectrum of $\mathrm{MN}_{2}$

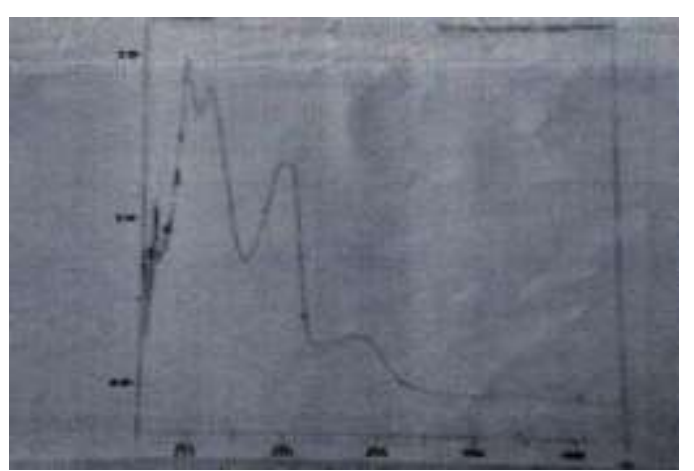

Figure 6: UV Spectrum of authenticated berberine

Compound $\mathrm{MN}_{3}$ : The compound $\mathrm{MN}_{3}$ is needle shaped orange red colored crystalline compound having $\mathrm{MP}-140^{\circ} \mathrm{C}$. It showed a clear Spot was observed in $30 \%$ methanol in $\mathrm{CHCl}_{3}$ with R.F value 0.81.It gave pale yellow precipitate in Meyer's test and orange red precipitate in Dragendroff's test which indicated that the compound was alkaloid. The IR peaks were $4420 \mathrm{~cm}^{-1}, 3996.51 \mathrm{~cm}^{-1}, 3340.71 \mathrm{~cm}^{-1}, 3240.41$ $\mathrm{cm}^{-1}\left(\mathrm{~N}-\mathrm{H}\right.$ stretch), $3062.96 \mathrm{~cm}^{-1} \quad, 3016.67 \mathrm{~cm}^{-1}$, $2947.23 \mathrm{~cm}^{-1}, 2885.52 \mathrm{~cm}^{-1}, 2831.50 \mathrm{~cm}^{-1}$ (C-H stretch in aromatic functional group), 2762.06 $\mathrm{cm}^{-1}, 2654.05 \mathrm{~cm}^{-1}, 2623.19 \mathrm{~cm}^{-1}, 2376.30 \mathrm{~cm}^{-1}$, $2345.44 \mathrm{~cm}^{-1}$ (N-H stretch), $2121.70 \mathrm{~cm}^{-1}, 2052.26$ $\mathrm{cm}^{-1}$ (C triple bond $\mathrm{N}$ stretch) $1928.82 \mathrm{~cm}^{-}$
, $1604.77 \mathrm{~cm}^{-1}, 1527.62 \mathrm{~cm}^{-1} \quad$ (C-C stretch in aromatic), $1442.75 \mathrm{~cm}^{-1}$ (C-H bending), 1018.41 $\mathrm{cm}^{-1} \quad$ (C-O-C stretch) ,972.12 $\mathrm{cm}^{-1}(\mathrm{O}-\mathrm{H}$ bending), $900.40 \mathrm{~cm}^{-1}, 879.54 \mathrm{~cm}^{-1}, 807.82 \mathrm{~cm}^{-1}$, $600.8 \mathrm{~cm}^{-1}, 509.21 \mathrm{~cm}^{-1}, 362.62 \mathrm{~cm}^{-1}$ (C-H out of plane bending). The IR peaks of authentic sample of 7,8 dihydro methoxy berberine were $1605 \mathrm{~cm}^{-1}, 1510 \mathrm{~cm}^{-1}, 1050 \mathrm{~cm}^{-1}, 975 \mathrm{~cm}^{-1}$, and 850 $\mathrm{cm}^{-1}$ [21]. The fingerprint region peaks of isolated compound were very much identical with that of the authentic sample 7,8-Dihydro-8methoxy berberine for IR spectrum of $\mathrm{MN}_{3}$ (Figure 7)

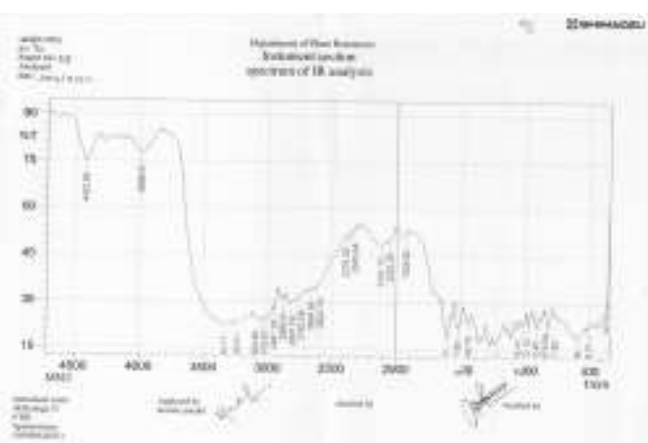

Figure 7: IR Spectrum of $\mathrm{MN}_{3}$

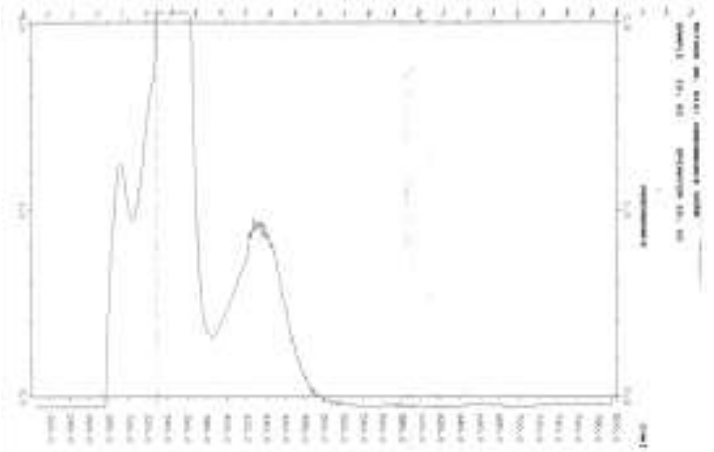

Figure 8: UV Spectrum of $\mathrm{MN}_{3}$

The UV spectral data $\lambda \max / \mathrm{nm}(\mathrm{EtOH})$ of the authentic sample were 285 and 365. The UV spectral data of 7,8-Dihydro-8-methoxy berberine were very much identical with that of the authentic sample 7,8-Dihydro-8-methoxy berberine (Figure 9). Comparing these spectral data of IR Spectra and UV spectra and melting point with reference to the authentic sample, compound $\mathrm{MN}_{3}$ may be 7,8-Dihydro-8-methoxy berberine.The confirmation of compound is in progress. The structure of 7, 8-Dihydro-8methoxy Berberine (Error! Reference source not found.9). 


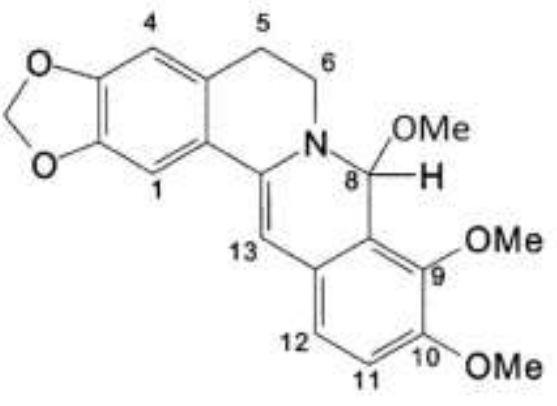

Figure 9: Chemical structure of 7, 8-Dihydro-8methoxy Berberine

Compound $\mathrm{MN}_{4}$ : A needle shaped dark Orange brown colored crystalline compound $\mathrm{MN}_{4}$ was obtained in pure and dry state. A sharp melting

Table 3: Antimicrobial Susceptibility test

\begin{tabular}{llllll}
\hline \multirow{2}{*}{ Crude extract } & \multirow{2}{*}{ Vol. of extract } & \multicolumn{2}{c}{ Staphylococcus aureus } & \multicolumn{2}{c}{ Kleibsella pneumonia } \\
\cline { 3 - 6 } & & & control & & control \\
\hline Hexane stem extract of M.nepalensis & $30 \mu \mathrm{l}$ & Resistant & $21 \mathrm{~mm}$ & Resistant & $30 \mathrm{~mm}$ \\
Ethyl acetate stem extract of M.nepalensis & $30 \mu \mathrm{l}$ & Resistant & $21 \mathrm{~mm}$ & Resistant & $30 \mathrm{~mm}$ \\
Methanol stem extract of M.nepalensis & $30 \mu \mathrm{l}$ & $18 \mathrm{~mm}$ & $21 \mathrm{~mm}$ & Resistant & $30 \mathrm{~mm}$ \\
Hexane stem extract of B. aristata & $30 \mu \mathrm{l}$ & $7 \mathrm{~mm}$ & $21 \mathrm{~mm}$ & Resistant & $30 \mathrm{~mm}$ \\
Ethyl acetate stem extract of B. aristata & $30 \mu 1$ & $14 \mathrm{~mm}$ & $21 \mathrm{~mm}$ & Resistant & $30 \mathrm{~mm}$ \\
Methanol stem extract of B. aristata & $30 \mu 1$ & $21 \mathrm{~mm}$ & $21 \mathrm{~mm}$ & Resistant & $30 \mathrm{~mm}$ \\
Hexane leaf extract of B. aristata & $30 \mu 1$ & Resistant & $21 \mathrm{~mm}$ & Resistant & $30 \mathrm{~mm}$ \\
Ethyl acetate leaf extract of B. aristata & $30 \mu 1$ & Resistant & $21 \mathrm{~mm}$ & Resistant & $30 \mathrm{~mm}$ \\
Methanol leaf extract of B. aristata & $30 \mu 1$ & Resistant & $21 \mathrm{~mm}$ & Resistant & $30 \mathrm{~mm}$ \\
Hexane leaf extract of M.nepalensis & $30 \mu 1$ & Resistant & $21 \mathrm{~mm}$ & Resistant & $30 \mathrm{~mm}$ \\
Ethyl acetate leaf extract of M.nepalensis & $30 \mu \mathrm{l}$ & Resistant & $21 \mathrm{~mm}$ & Resistant & $30 \mathrm{~mm}$ \\
Methanol leaf extract of M.nepalensis & $30 \mu 1$ & Resistant & $21 \mathrm{~mm}$ & Resistant & $30 \mathrm{~mm}$
\end{tabular}

point was found to be $140^{\circ} \mathrm{C}$ and decomposed at $160^{\circ} \mathrm{C}$. A clear Spot was observed in $30 \%$ methanol in $\mathrm{CHCl}_{3}$ with R.F value 0.86 . Furthermore, it gave pale yellow precipitate in Meyer's test and orange red precipitate in Dragendroff's test which indicated that the compound was alkaloid. The exact structure and name of the compound will be confirmed after analysis of NMR, Mass and UV spectra.

\section{Biological activities of plant extract The antimicrobial susceptibility test}

The study involved the antimicrobial activity tests of the different extracts. Different bacteria were used for the test of the activity of the extracts. The results of the qualitative antimicrobial screening of different extracts were as shown in (Table 3).

\section{Comparative Study of anti- microbial activity}

The results of the antimicrobial susceptibility test of the different extracts showed that the crude hexane extracts and ethyl acetate extract of stem and leaf of $M$. nepalensis were resistant to all of the bacteria species tested while ethyl acetate extract of $B$. aristata was found to be moderately active against Staphylococcus aureus while hexane extract of stem of B. aristata was slightly active against $S$. aureus. But the methanol extracts of stem of both plant species were found to be strongly active towards the gram positive bacteria Staphylococcus aureus. The methanol extract of $B$. aristata showed same pharmacological effect of Nalidixic acid control while methanol extract of $M$. nepalensis showed little lower pharmacological effect than that of control. Hence both of these methanol extract of $M$. nepalensis and $B$. aristata were pharmacologically active against Staphylococcus aureus while they were resistant to bacteria Kleibsella pneumonia. The methanol extract of leaf of both plant species were also found to be resistant to above bacteria species. DMSO was used as solvent control and it showed no effect. It was also found that Salmonella typhimurim and Salmonella typhimurium strains of bacteria were resistant to Nalidixic acid (Data not shown)

\section{Brine Shrimp Bioassay}

For the study of biological activity of plant material, the newly hatched brine shrimp nauplii were exposed to the plant extracts. The biological activities were evaluated on the basis of their toxicities towards these nauplii. In this 
method, $\mathrm{LC}_{50}$ values $(\mu \mathrm{g} / \mathrm{ml})$ for different fractions were determined and those having less than 1000 are considered as pharmacologically active. The results obtained during this study are given in (Table 4).

Table 4: cytotoxicity value of different plant extracts

\begin{tabular}{ll}
\hline Methanol Extract & $\mathrm{LC}_{50}(\mu \mathrm{g} / \mathrm{ml})$ \\
\hline Stem of M.nepalensis & 8.3 \\
Leaf of M.nepalensis & 389.04 \\
Stem of B. aristata & $8.058^{*} 10^{-4}$ \\
Leaf of B. aristata & 1303.166 \\
\hline
\end{tabular}

Comparative Study of Cytotoxicity against Brine shrimps

The results of Brine shrimp bioassay showed that stem and leaf of Mahonia nepalensis have 8.3 $(\mu \mathrm{g} / \mathrm{ml})$ and $389.04(\mu \mathrm{g} / \mathrm{ml}) \mathrm{LC}_{50}$ values while stem of Berberis aristata have $8.058^{*} 10^{-4}(\mu \mathrm{g} / \mathrm{ml})$ $\mathrm{LC}_{50}$ values which showed their bio-activity. Stem of Berberis aristata and Mahonia nepalensis were comparatively highly cytotoxicity while leaf of Mahonia nepalensis was moderately cytotoxic and leaf of Berberis aristata was found to pharmacologically inactive against brine shrimp.

\section{Conclusion}

Phytochemical screening of hexane extract, ethyl acetate extracts and methanol extracts of the two plants revealed the presence of quinones, glycoside, terpenoid, cardiac glycoside, and steroid. However, Alkaloids was found in all type of stem extracts. Hence, distribution of different group of compounds was somewhat phytochemical equivalent in both species. The column chromatography of methanol extract of stem of Mahonia nepalensis resulted in isolation of four different compounds $\mathrm{MN}_{1}, \mathrm{MN}_{2}, \mathrm{MN}_{3}$ and $\mathrm{MN}_{4}$ in which compound $\mathrm{MN}_{1}$ was identified as $\beta$-Sitosterol for the first time and $\mathrm{MN}_{2}$ as Berberine. Metabolic stem extract of Mahonia nepalensis and Berberis aristata both were strongly pharmacologically active as that of Nalidixic acid against Staphylococcus aureus. The hexane and ethyl acetate extract of stem and leaf of Mahonia nepalensis were resistant to all of the bacterial species whereas hexane extract ethyl acetate extract of Berberis aristata were pharmacologically active against Stappylococcus aureus. In addition, all the other extracts were found to be inactive against Gram negative Bacteria like Kleibsella Pneumoniae, Salmonella typhimurim, Salmonella typhimurim. Methanol stem extract of Mahonia nepalensis and methanol stem extract of Berberis aristata were highly cytotoxic against Brine shrimp while leaf of Mahonia nepalensis was moderately cytotoxic and leaf of Berberis aristata was pharmacologically inactive against brine shrimp nauplii.

\section{Conflict of interest}

The authors declare no conflict of interest.

\section{Author contribution}

R.T was responsible for performing research under the supervision of S.M. R.T performed bibliographic researches and participated in discussion. The manuscript was designed, organized and written and edited by R.T. All authors have read and approved the final manuscript.

\section{Ethical Clearance}

No ethical rules had been violated during sample collection and experimentation. Sample of Mahonia nepalensis and Berberis aristata had been collected from Bhaktapur and Palpa.

\section{Fund source}

The research had been conducted from personal fund. Central Department of Chemistry, Tribhuwan University, Nepal had allowed conducting the research in the laboratory of Chemistry department.

\section{Acknowledgement}

Authors are sincerely grateful to the Head of Department, Prof. Dr. Megh Raj Pokhrel and Former Head of Department, Dr. Kedar Nath Ghimire of Central Department of Chemistry, Tribhuvan University for supporting and providing laboratory access in Central Department of Chemistry. We are also grateful to Dr. Amar Prasad Yadav, Dr. Surya Kant Kalauni and Dr. Bimala Subba for their kind cooperation and all the members of Central Department of Chemistry.

\section{References}

1. Shrestha KK, Tiwari NN, Ghimire SK: MAPDON-Medicinal and Aromatic Plant Database of Nepal. In Proceedings Of Nepal 
Japan Joint Symposiumon Conservation And Utilization of Himalayan Medicinal Resources, (eds)Watanabe T.A.; Takano; Bista, M.S. and Sainju, H.K. NonProfit Organization (NPO)/Society for Conservation And Development of Himalayan Medicinal Resources(SCDHMR)Japan, 2002: 53-74

2. Phooboo S, Devkota A, Jha PK: Medicinal Plants In Nepal. An Anthology Of Contemporary Research. 2008: 1-24

3. Polium O, Stainton A: Flowers of Himalaya. Oxford University Press, Oxford India Paperbacks: 20-22

4. Plant Database Facts Sheet (http:/ / www.Plantdatabase.net/Mahonia nepalensis) (Accessed 27 April, 2013)

5. Govindachari TR, Pai BR, Rajadurai, S, Rao UR: Alkaloids of Mahonia nepalensis D.C. J Ind Chem Soc. 1957: 41-48

6. Nguyen TM, Tran AT, Hoang TH, Chau VM, Ninh $K B$, Phan VK : Secobisbenzylisoquinoline Alkaloid From Mahonia nepalensis D.C. J Chem. 200746 (5), 63-68

7. Nguyen TM, Tran AT, Hoang TH, Chau VM, Nin KB, Phan VK: Bisbenzylisoquinoline Alkaloid From Mahonia nepalensis, J Chem. 2009 47(3): 365-370

8. Sharma K, Bairwa R, Chauhan N, Shrivastava B, Saini NK: Berberis Aristata. Indian J Re Ayu Pharm. 2011 2(2): 383-388

9. Chatterjee RP: J Indian Chem Soc. 1951, 28: 225

10. Blasko G: Karachine: An Unusual Protoberine Alkaoid. J Amer Chem Soc. 1982 104(7): 2039 2041

11. Blasko G, Sharma, M, Taxilamine: A Pseudobenzylpyroquinoline Alkaoid. Heterocycle 1982 1982 19(2): 257-259

12. Rahmann A, Ansari AA: Alkaloids of Berberis Aristata -Isolation of Aromaline And Oxyberberine. J Chem Soc Pak. 1983 5(4): 283

13. Bhakuni DS, Shoheb A, Poppali SP: Medicinal Plants: Constituents of Berberis aristata. Indian J Chem. 1968 6(2): 123

14. Katiyar D, Singh RK, Singh S, Singh V: Isolation and Characterization Of Lanost-5en-3 $\beta$-ol From The Heart Wood of Berberis aristata DC, IJPI's J Pharmacog Herb Form. 2011 1(3): 8-13

15. Saied S, Batool S, Naz S: Phytochemical study of B. aristata. J of basic $\mathcal{E}$ applied science, 2007 3(1): $1-4$

16. Alamzeb M, Khan, MR, Ali S, Shah, SQ, Mamoon, and UR: Antimicrobial Properties Of extracts and compounds isolated from Berberis jaeschkeana. Bangladesh J Pharmacol. 2013 8: 107-109

17. Talukdar A, Chaudhary B: Phytochemical Screening of ethanolic extracts of
Rubiacordiofolia, Pharma E Bio. Sci., 2010, 1(4): 530-536

18. Culei I: Comparative antioxidant activity of individual herbal components used in Ayurvedic medicine. Phytochemistry 2003 63(1): 97-104

19. Perez C, Bazevquo PM: An Antibiotic assay by the Agar Well Diffusion method. Acta Biologicae et Medicine Experimentalis. 1990 15: 113-115

20. Meyer BN, Ferrigni NR, Putnam JE, Jacobsen LB, Nichols DE, McLaughlin JL: Brine Shrimp: A Convenient General Bioassay for Active Plant Constituents. J Med Plan Res. 1982 45: 3134

21. Tian JH, Yang CW: Chemical Constituents from The Stem of Mahonia japonica. J Chi Chem Soc. 2004 51: 443-446 